\title{
RESEARCH
}

Open Access

\section{Study of desertification sensitivity in Talh region (Central Tunisia) using remote sensing, G.I.S. and the M.E.D.A.L.U.S. approach}

\author{
Chokri Bedoui
}

\begin{abstract}
Background: Tunisia is one of countries most affected by desertification. Sustainability of its resources, particularly agricultural ones, is closely dependent on it. Studies have multiplied to understand this phenomenon and consequently try to reduce its consequences on society. In recent decades, attempts have been made to find methods of forecasting and predicting desertification. Today, with significant progress made in remote sensing and GIS techniques, there is a better control of data from field, environment and society. This now makes it possible to produce documents that are much more accurate and reliable than before. This paper aims to assess sensitivity to desertification in a region of central Tunisia using remote sensing tools, GIS and guidelines of MEDALUS (Desertification and Land Use in the Mediterranean) model. Integration of different parameters with weighted values in a GIS system resulted in indices of climate, soil, vegetation and management.

Result: In almost all cases, indices reveal the preponderance of soils, vegetation, climate and management of moderate and especially poor quality. Overlaying the four indices by multiplying them according to model equation yields the final sensitivity index map. This index shows that study area is in an advanced stage of desertification since most of its surface area (82\%) is in critical class. The rest is considered as fragile. Whole region is therefore placed in of high sensitivity classes of desertification. This situation is linked to a very poor vegetation cover, unstructured and low-developed soils, cultural practices based on tillage and high livestock numbers in regard to low natural grazing resources. It is also due to a farming system not taking into account soil natural vulnerability.

Conclusion: As natural resources, in current context of exploitation, cannot regenerate so quickly, pressure on environment is remarkable, exacerbating at the same time desertification problem. Continuing with current practices with clear signs of degradation may make situation irreversible in near future. Therefore, immediate action is necessary to stop degradation and preserve future generations' resources.
\end{abstract}

Keywords: Desertification sensitivity, GIS, Remote sensing, Medalus, Tunisia

Correspondence: chokribedoui@outlook.com

Department of Geography, University of Sfax, Sfax, Tunisia

\section{Springer Open}

(c) The Author(s). 2020 Open Access This article is licensed under a Creative Commons Attribution 4.0 International License, which permits use, sharing, adaptation, distribution and reproduction in any medium or format, as long as you give appropriate credit to the original author(s) and the source, provide a link to the Creative Commons licence, and indicate if changes were made. The images or other third party material in this article are included in the article's Creative Commons licence, unless indicated otherwise in a credit line to the material. If material is not included in the article's Creative Commons licence and your intended use is not permitted by statutory regulation or exceeds the permitted use, you will need to obtain permission directly from the copyright holder. To view a copy of this licence, visit http://creativecommons.org/licenses/by/4.0/. 


\section{Introduction}

Desertification is a transformation of land that was not desertic into land recalling desert landscapes. It is a scourge that affects many of world' s countries. Its occurrence is closely linked to population growth, remarkable expansion of crops sometimes on naturally fragile environments and inadequate farming practices in relation to soil conditions. Desertification occurs in a region because of lack of water reserves, soils are humus-depleted and rather destructured, and vegetation has become scarce and sparse. But also, because poor soils have been forced to produce by repeated and harmful ploughing. Desertification's consequences can be disastrous for societies and can impact stability of affected countries. Tunisia has experienced an intensification of desertification in recent decades, which is made more noticeable particularly during dry periods.

According to national institute of strategic studies, $96 \%$ of Tunisian territory is directly or indirectly affected by desertification (Institut national des études stratégiques (Tunisie) 2017). In addition, a study conducted by INRA (France), a $2^{\circ} \mathrm{C}$ increase in global average temperature by 2050 will cause North African countries to lose half their cultivable land (Le Mouël et al. 2015). In these rather alarming perspectives, research has multiplied to understand underlying causes and attempt to predict phenomenon's evolution.

Originally steppic and covered by formations based on zizyphus lotus and acacia raddiana, study region is currently suffering from erosion phenomena, especially eolian, which is damaging soil reserves and seriously threatening sustainability of crops. Environmental sensitivity to desertification can be defined, in this context, as a response of an environment, or part of it, to a change in one or more factors (Basso et al. 1999). These factors are climate, vegetation, soils and management. Sensitivity of a region to desertification can be assessed by several methods. But with advent of remote sensing and GIS, it is now possible to integrate an infinite number of parameters interacting in emergence and evolution of desertification. Therefore, MEDALUS model allows an assessment of desertification sensitivity to be performed (Kosmas et al. 1999). And this is obtained by calculating weighted values of soil characteristics (texture, parental material, depth,

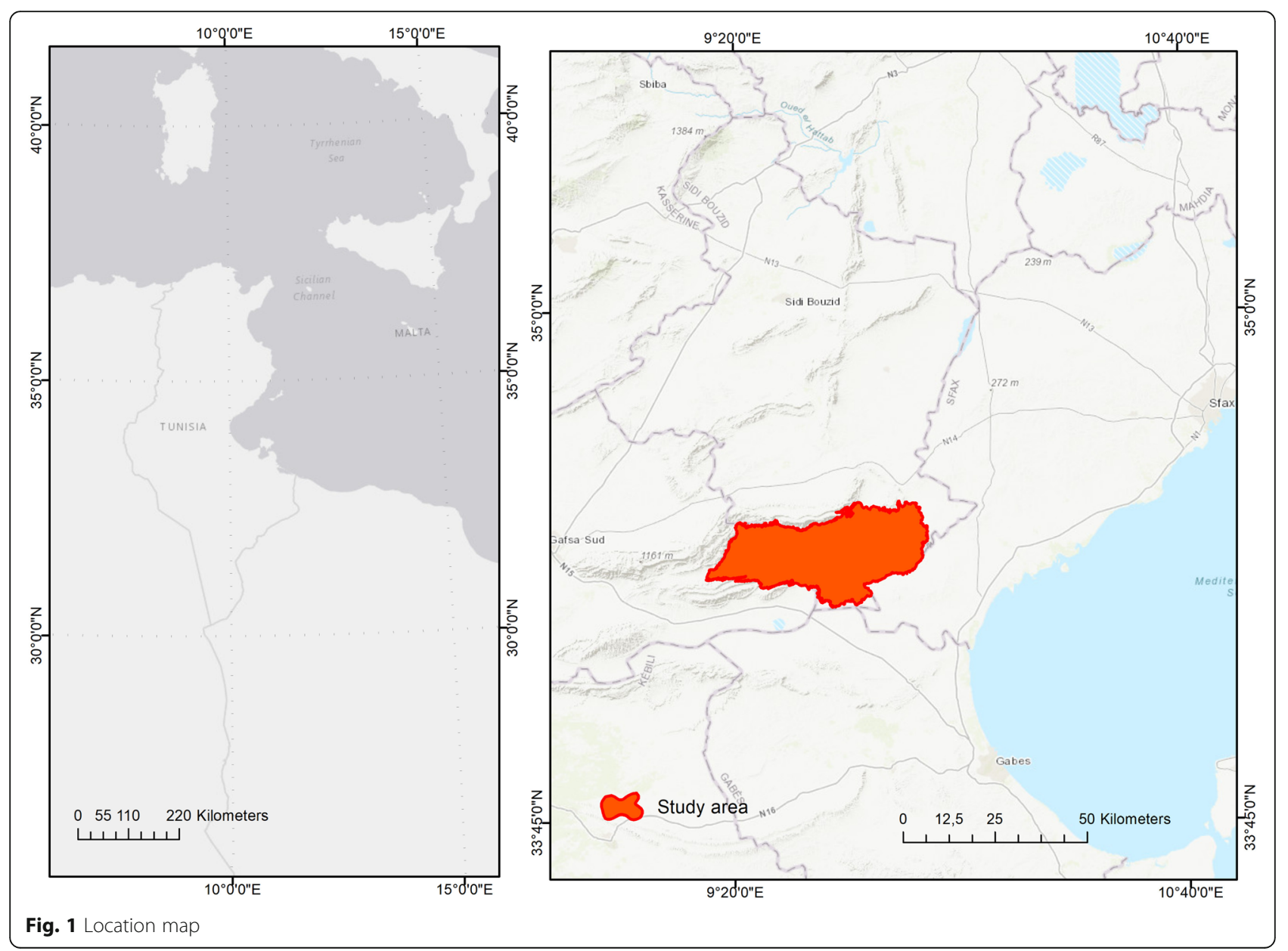


drainage, etc.), vegetation (cover, fire resistance, etc.), climate (rainfall, evapotranspiration, aridity, etc.) and management (land use, overgrazing, etc.) to have values at the end that are geometric mean of all these parameters and that will reflect sensitivity state.

Since model's guidelines were published, several studies in Mediterranean countries and in others have been carried out to assess desertification risks. In addition, this model allows modifying parameters according to basic data availability for each case. Therefore, Sepehr et al (2007) tried to assess desertification sensitivity in southern Iran, Lahlaoi et al. (2017) in Wadi Melah basin (northern Morocco), Boudjemline and Semar (2018) and Bouhata and Kalla (2014) in Algeria, Basso et al. (1999) in southern Italy, Kamel et al. (2015) in Lebanon, Budak et al. (2018) in Turkey, Momirović et al. (2018) in Serbia, (Vieira et al. (2015) in north-eastern Brazil and Malhue and Isabel (2018) in Chile. In these studies, authors have in each case added or excluded parameters concerning soils, climate or management and sometimes even added new indexes that did not exist in initial document, such as physical quality index including geomorphological, geological and pedological data (Vieira et al. 2015). Results are in correlation with physical and climatic conditions in each region, but it is appropriate to note that adopting same parameters, following model's weighting values and properly assigning values in first steps are very important in an evaluation or comparison process between studies using this model.

\section{Study region}

Study area is in central Tunisia between $9^{\circ} 20^{\prime}$ to $9^{\circ} 52^{\prime}$ East and between $34^{\circ} 15^{\prime}$ to $34^{\circ} 29^{\prime}$ North (Fig. 1). It is composed mainly of plains that rises slightly on north and west sides only because of slight slopes at neighboring relief piedmont. Altitudes are less than $100 \mathrm{~m}$ in $90 \%$ of region's terrain but can reach $341 \mathrm{~m}$ on foothills of northern and western reliefs (Fig. 2). To south-east extends the Naouel sebkha (salt flat), which represents a local base level for region's temporary watercourses. Study region corresponds to two synclines. The first is in western part and is bounded to north by the Large Bouhedma

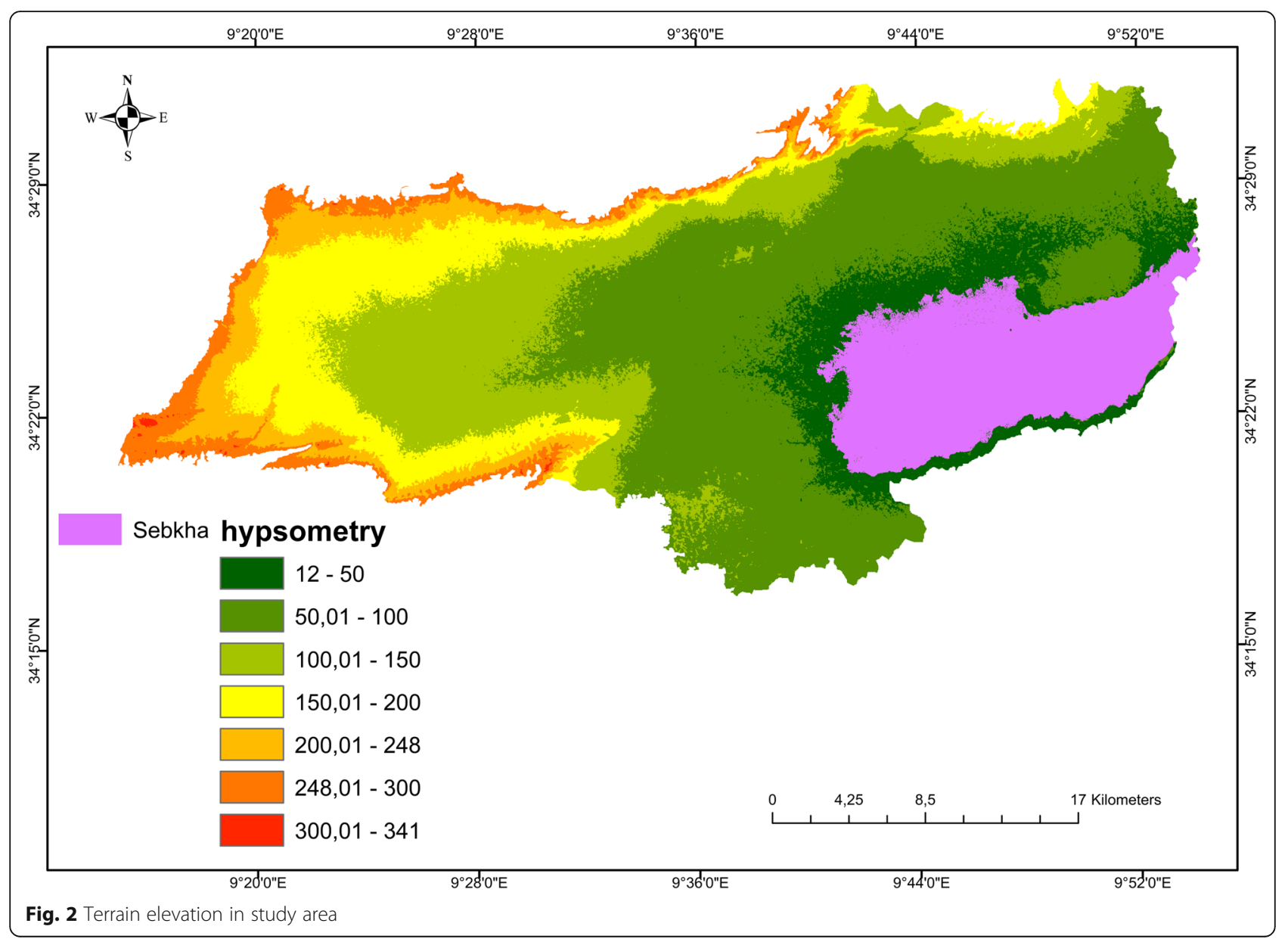




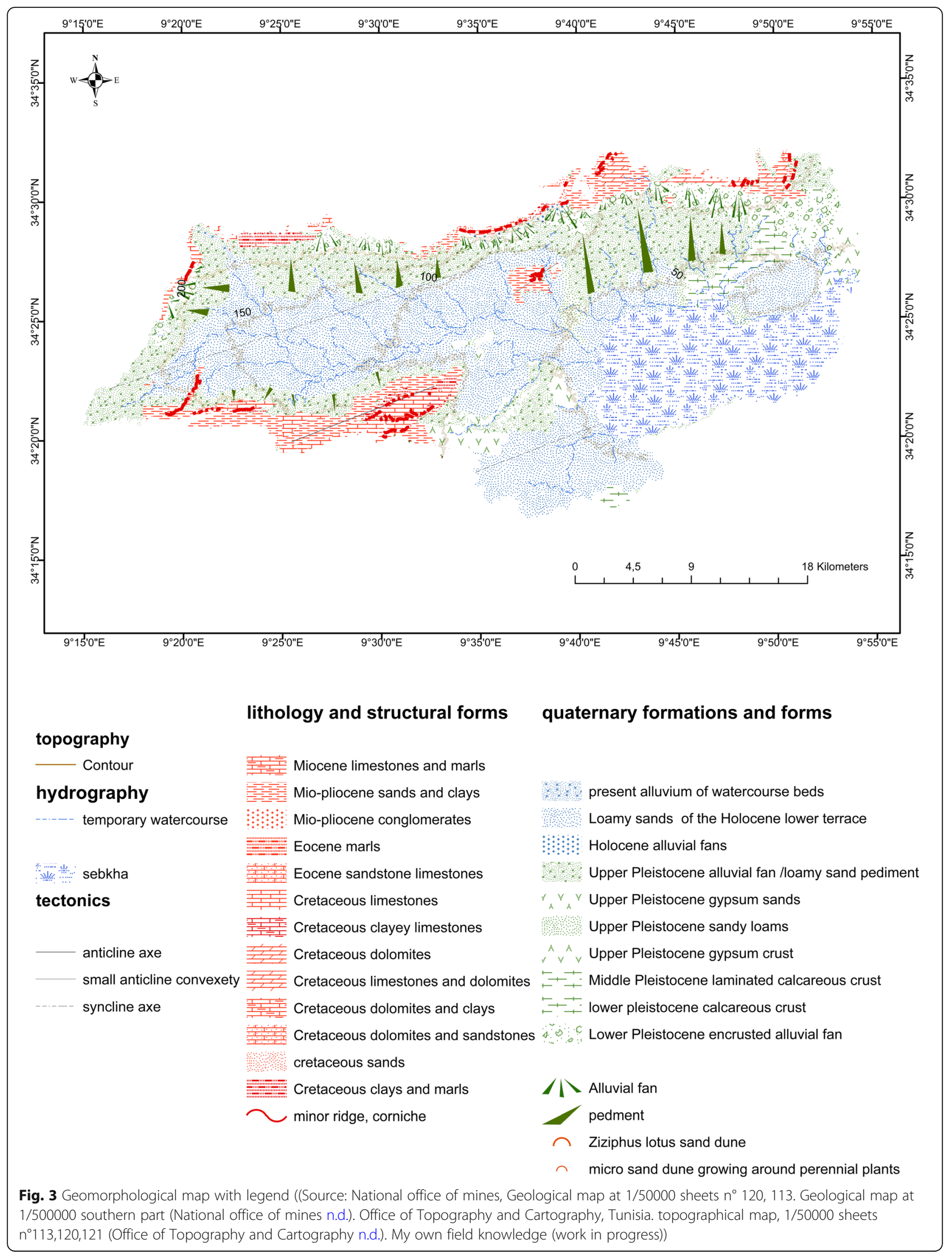




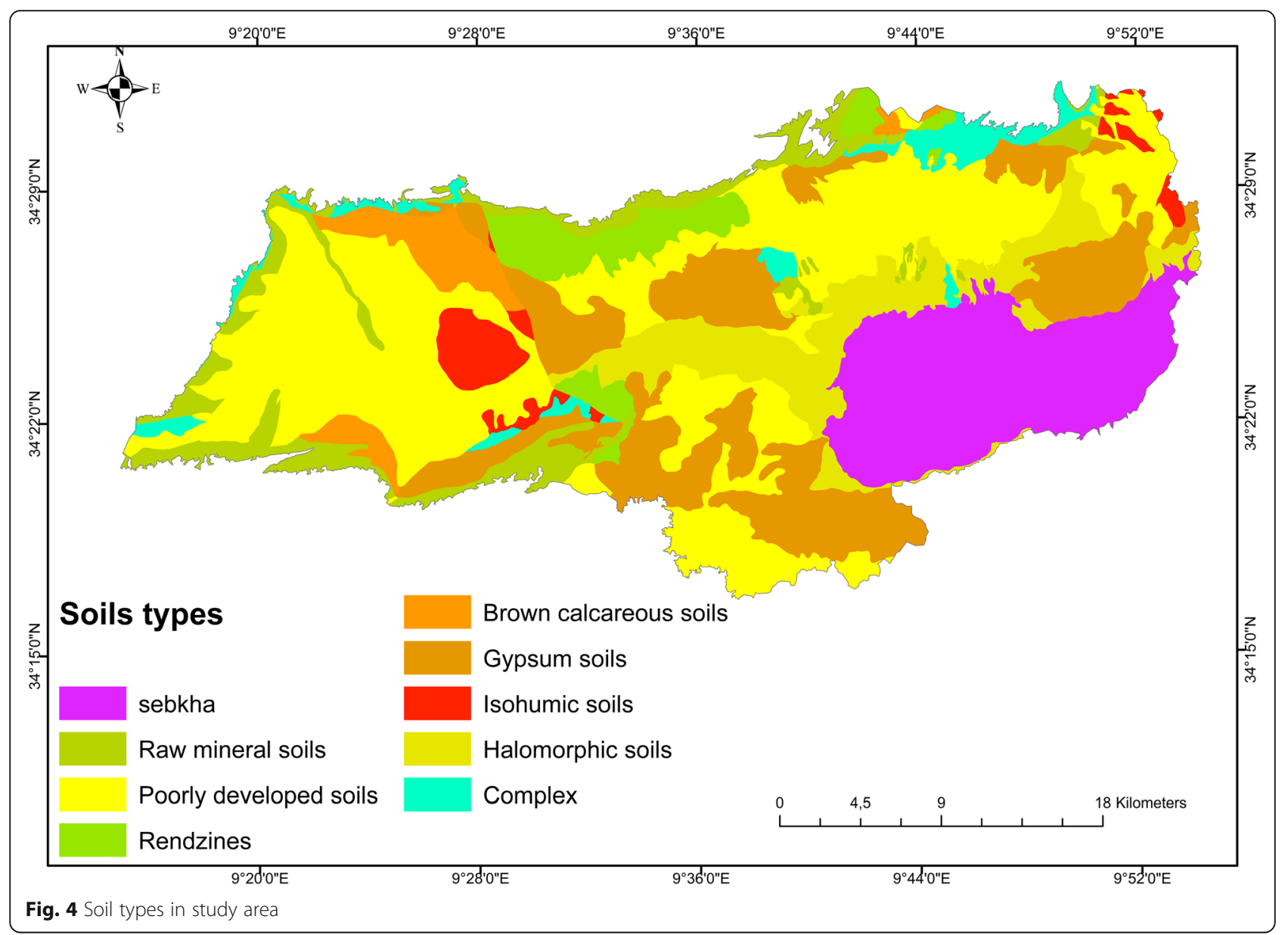

Anticline and to south by the Small Chemsi and Belkhir Anticlines. The second, located in eastern part and corresponds to the Naouel sebkha. It is bordered only by small anticlinal convexities. Geological formations outcropping in study area are varied. But since these are often low plains, surface formations are of miopliocene and quaternary age. Piedmont of

Table 1 Soil types in study area

\begin{tabular}{lllc}
\hline Category & Soil type & $\%$ & \% category \\
\hline Salty soils & Gypsum soils & 18.69 & 42.4 \\
& Halomorphic soils & 9.45 & \\
& Sebkha & 14.26 & \\
Poor soils & Raw mineral soils & 8.09 & 43.02 \\
& Poorly developed soils & 34.93 & \\
Valuable soils & isohumic soils & 2.74 & 21.14 \\
& Rendzine & 4.80 & \\
& Complex soil & 3.25 & \\
& Brown calcareous soils & 3.55 & \\
\hline
\end{tabular}

northern reliefs is site of chaotic accumulations of alluvial fans of various ages (Fig. 3). To east, Pleistocene limestone crusts cover pediments or old alluvial fans. To west, limestone and gypsum crust predominate on surface. But most of study region corresponds to alluvial layers from Upper Pleistocene to Holocene. On surface, sand dunes built by Ziziphus lotus trees are scattered all over the field, including on land of the natural reserve. Small sand dunes created by perennials are also very frequent on flat areas.

Study region is constituted of salty soils with $42 \%$ of total area, $43 \%$ of poor or mineral soils and only $21 \%$ of valuable soil usable in agriculture (Fig. 4) (Table 1).

Natural vegetation is composed of a steppe of Acacia raddiana, Zizyphus lotus for trees and shrubs category. Perennials are composed in most areas by Astragalus armatus, Rantherium suavolens, Arthrophytum schmittianum, Pegnum harmala, Salsola vermiculata, Lycium arabicum, Artemisia campestris and Artemisia herba-alba. Stream beds are occupied by riparian species such as Tamarix gallica and Nerium oleander. 
Table 2 Data sources

\begin{tabular}{|c|c|c|}
\hline Data source & Parameter & Reference \\
\hline $\begin{array}{l}\text { Merra_2 } \\
\text { climatological gridded } \\
\text { data }\end{array}$ & $\begin{array}{l}\text { Rainfall, temperature (to calculate } \\
\text { evapotranspiration and aridity index) }\end{array}$ & $\begin{array}{l}\text { (c) MERRA. (http://www.soda-pro.com/web-services/meteo-data/merra) } \\
\text { (NASA n.d.-b) }\end{array}$ \\
\hline $\begin{array}{l}\text { Carte Agricole (digital } \\
\text { database) }\end{array}$ & $\begin{array}{l}\text { Soil texture, soil depth, soil parental rock, } \\
\text { drainage, rock fragment, natural reserve } \\
\text { boundary. }\end{array}$ & Ministry of agriculture, Tunisia (2001) (Ministry of agriculture 2001) \\
\hline $\begin{array}{l}\text { Sentinel_2_1c } 10 \mathrm{~m} \\
\text { resolution satellite } \\
\text { image }\end{array}$ & $\begin{array}{l}\text { Cropland, fire resistance, drought protection, } \\
\text { erosion protection, plant cover (by using NDVI } \\
\text { index) }\end{array}$ & $\begin{array}{l}\text { (c) Copernicus open access hub (Copernicus open access hub n.d.) } \\
\text { https://scihub.copernicus.eu/dhus/\#/home }\end{array}$ \\
\hline $28 \mathrm{~m}$ resolution $\mathrm{DEM}$ & Aspect, slope. & $\begin{array}{l}\text { (c) NASA: ASTER GDEM Digital Elevation Model (NASA n.d.-a) } \\
\text { https://lpdaac.usgs.gov/dataset_discovery/aster/aster_products_table }\end{array}$ \\
\hline Socio-economical data & Population density, livestock data & $\begin{array}{l}\text { Office for Development of the Centre, Office for Development of the } \\
\text { South, the National Institute of Statistics: Statistics of governorates of Sidi } \\
\text { Bouzid and Gafsa (Institut national des statistiques 2014; Office de } \\
\text { développement du Centre ouest (ODCO) 2017; Office de développent du } \\
\text { Sud (ODS) 2017) }\end{array}$ \\
\hline Google earth imagery & Conservation practice (digitalization) & (c) Google earth Pro. app. \\
\hline
\end{tabular}

\section{Materials and methods}

Data sources can be summarized in following table (Table 2):

\section{Climate quality index}

Climate quality index was calculated from climatological data from MERRA-2 platform (Modern-Era Retrospective analysis for Research and Applications, Version 2) downloadable here (http://www.soda-pro.com/web-services/meteo-data/merra). Data range from 2008 to 2017 (NASA n.d.-b) (Table 3). These are gridded data including precipitation and temperatures among others. Temperatures in Kelvin have been converted to ${ }^{\circ} \mathrm{C}$. From these data, evapotranspiration values were obtained according to Thornthwaite equation (Thornthwaite 1948) (Eq. 1, 2 and 3) and then aridity index according to UNESCO equation (UNESCO - United Nations Educational: Scientific and Cultural Organization 1979; Sampaio et al. 2003) (Eq. 4) (Thornthwaite 1948):

Table 3 Main climatological data for study area (NASA n.d.-b)

\begin{tabular}{llllll}
\hline Long. & Lat. & Station & Rainfall & Evapotranspiration & Aridity \\
\hline 9.555 & 34.259 & Sidi Mansour & 166.9 & 1018.15 & 0.16 \\
9.39 & 34.414 & Haddej-village & 186.54 & 998.78 & 0.18 \\
9.6 & 34.465 & Elboua-village & 189.38 & 996.5 & 0.190 \\
9.699 & 34.481 & Station parc & 189.78 & 997.49 & 0.19 \\
9.843 & 34.572 & Mezzouna & 136.31 & 1016.95 & 0.13 \\
10.096 & 34.741 & Bir Ali & 208 & 997.5 & 0.20 \\
8.784 & 34.422 & Gafsa & 161.21 & 1017.03 & 0.15 \\
\hline
\end{tabular}

$$
\mathrm{ETP}=16 *\left[10 * \frac{\mathrm{T}}{\mathrm{P}}\right]^{\mathrm{a}} * \mathrm{~F}
$$

Where: ETP is mean evapotranspiration for a month, in $\mathrm{mm} ; \mathrm{T}$ is mean temperature for a month, in ${ }^{\circ} \mathrm{C}$. $\mathrm{F}$ is latitude corrective factor (Thornthwaite 1948).

$$
\mathrm{a}=0.016 \times \mathrm{I}+0.5
$$

Where: I is annual thermic index (Thornthwaite 1948).

Table 4 Assigned weighing indices for various parameters used for assessment of Climate quality (Kosmas et al. 1999; Vieira et al. 2015)

\begin{tabular}{lllll}
\hline Parameter & Class & Description & range & Weight \\
\hline Rainfall & 1 & High & $>300 \mathrm{~mm}$ & 1 \\
& 2 & Moderate & $150-300 \mathrm{~mm}$ & 1.5 \\
& 3 & Low & $<150 \mathrm{~mm}$ & 2 \\
Aridity & 1 & High & $\mathrm{Al} \geq 1$ & 1 \\
& 2 & Moderate & $0.1<\mathrm{Al}<1$ & 1.5 \\
& 3 & Low & Al $\leq 0.1$ & 2 \\
Aspect & 1 & Wet & North & 1 \\
& 2 & Dry & South & 2 \\
\hline
\end{tabular}


Table 5 Assigned weighing indices for various parameters used for assessment of soil quality (Kosmas et al. 1999)

\begin{tabular}{|c|c|c|c|c|}
\hline & Class & Description & & Weight \\
\hline \multirow[t]{4}{*}{ Texture } & 1 & Good & $\mathrm{L}, \mathrm{SCL}, \mathrm{SL}, \mathrm{LS}, \mathrm{CL}$ & 1 \\
\hline & 2 & Moderate & SC, SiL SiCL & 1.2 \\
\hline & 3 & Poor & $\mathrm{Si}, \mathrm{C}, \mathrm{SiC}$ & 1.6 \\
\hline & 4 & Very poor & S & 2 \\
\hline \multirow[t]{4}{*}{ Slope } & 1 & Very gentle to flat & $<6 \%$ & 1 \\
\hline & 2 & Gentle & $6-18 \%$ & 1.2 \\
\hline & 3 & Steep & $18-35 \%$ & 1.5 \\
\hline & 4 & Very steep & $>35 \%$ & 2 \\
\hline \multirow[t]{3}{*}{ Parent material } & 1 & Good & Shale, schist, basic, ultra-basic, Conglomerates, unconsolidated & 1 \\
\hline & 2 & Moderate & Limestone, marble, granite, Rhyolite, Ignimbrite, gneiss, siltstone, sandstone & 1.7 \\
\hline & 3 & Poor & Marl, Pyroclastics & 2 \\
\hline \multirow[t]{4}{*}{ Soil depth } & 1 & Deep & $>75$ & 1 \\
\hline & 2 & Moderate & $75-30$ & 2 \\
\hline & 3 & Shallow & $15-30$ & 3 \\
\hline & 4 & Very shallow & $<15$ & 4 \\
\hline \multirow[t]{3}{*}{ Drainage } & 1 & Well drained & & 1 \\
\hline & 2 & Imperfectly drained & & 1.2 \\
\hline & 3 & Poorly drained & & 2 \\
\hline \multirow[t]{3}{*}{ Rock fragments } & 1 & Very stony & $>60$ & 1 \\
\hline & 2 & Stony & $20-60$ & 1.3 \\
\hline & 3 & Bare to slightly stony & $<20$ & 2 \\
\hline
\end{tabular}

L loam, SCL sandy clay loam, SL sandy loam, LS loamy sand, CL clay loam, SC sandy clay, SiL silty loam, SiCL silty clay loam, Si silt, C clay, SiC silty clay, S sand

$$
I=\sum_{m=1}^{12} i(m),=\left[\frac{T(m)}{5}\right]^{1.514}
$$

Aridity Index (UNESCO - United Nations Educational: Scientific and Cultural Organization 1979):

$$
\mathrm{AI}=\frac{\mathrm{P}}{\mathrm{Etp}}
$$

Where $P$ is mean annual precipitation and Etp is mean annual potential evapotranspiration.

Land exposition (Aspect) was generated from a DEM of $28 \mathrm{~m}$ resolution and simplified in only two directions which are north and south. Then three climate parameters were weighted according to scores proposed by Medalus model (Table 4). Calculation of climate quality index is achieved by multiplying these three layers as follows (Eq. 5):

$$
\mathrm{CQI}=(\text { rainfall } * \text { aridity } * \text { aspect })^{1 / 3}
$$

\section{Soil quality index}

Soil quality index was calculated from data provided by Carte Agricole (agricultural map) of Ministry of Agriculture (Fig. 4). These are soil texture, depth, parent rocks, rock fragments and drainage. Scores were assigned according to Medalus guidelines (Table 5). Map is obtained by multiplying different scores with following equation (Eq. 6):

$$
\begin{aligned}
\mathrm{SQI}= & (\text { texture } * \text { parent material } \\
& * \text { rock fragment } * \text { depth } * \text { slope } * \text { drainage })^{1 / 6}
\end{aligned}
$$

\section{Vegetation quality index}

Vegetation quality index was calculated using data from Senitinel_2_1c satellite image with a resolution of $10 \mathrm{~m}$. First, land cover map was obtained from calculation of NDVI index, which shows vegetation density by intersecting the two red and infrared channels of Sentinel_2_ 


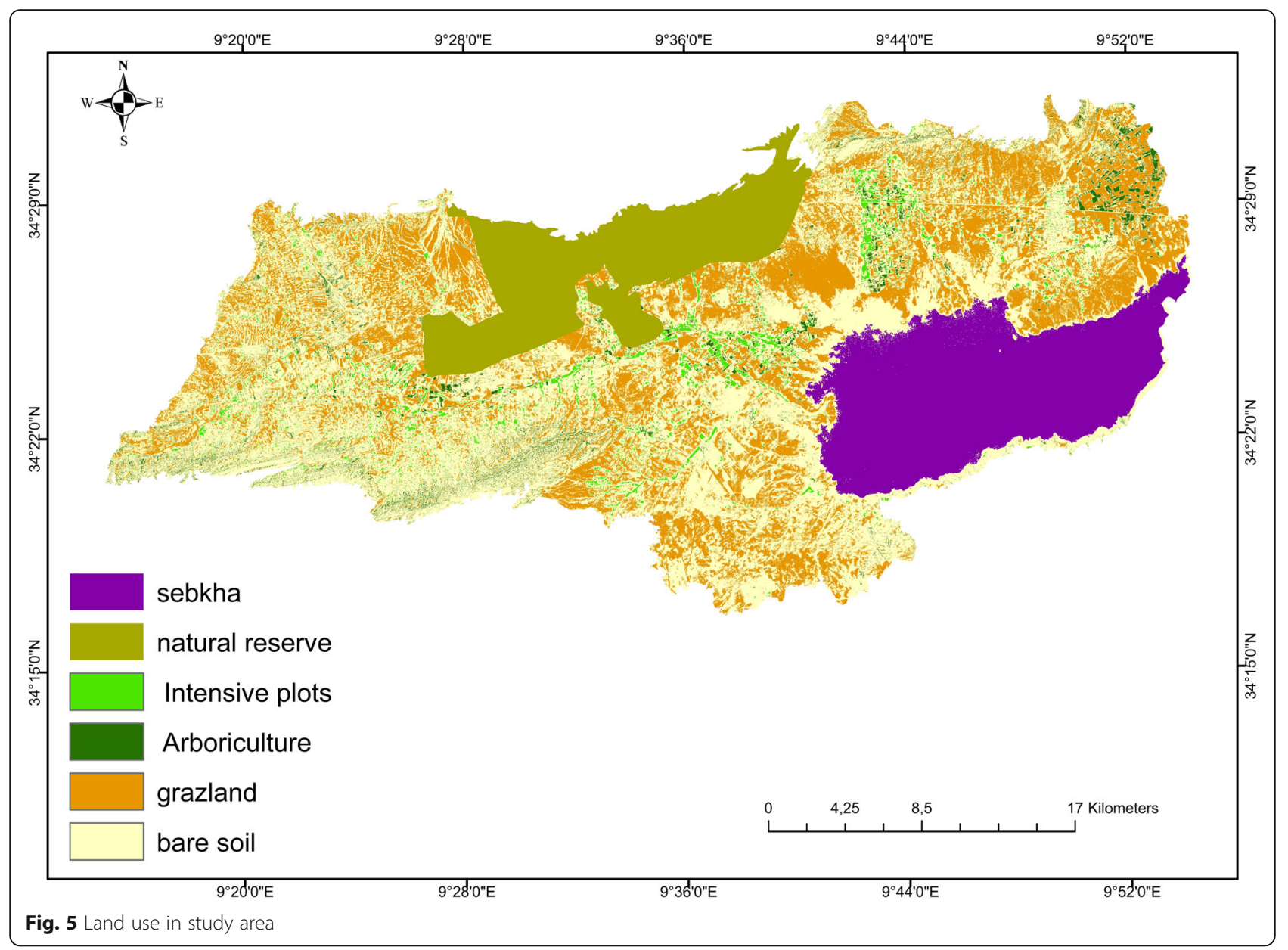

Table 6 Assigned weighing indices for various parameters used for assessment of vegetation quality (Kosmas et al. 1999)

\begin{tabular}{|c|c|c|c|c|}
\hline Parameter & Class & Description & Type of vegetation & Weight \\
\hline \multirow[t]{4}{*}{ Fire risk } & 1 & Low & bare land, perennial agricultural crops, annual agricultural crops (maize, tobacco, sunflower) & 1 \\
\hline & 2 & Moderate & $\begin{array}{l}\text { annual agricultural crops (cereals, grasslands), deciduous oak, (mixed), mixed Mediterranean, } \\
\text { macchia/evergreen forests }\end{array}$ & 1.3 \\
\hline & 3 & high & Mediterranean macchia & 1.6 \\
\hline & 4 & Very high & pine forests & 2 \\
\hline \multirow[t]{5}{*}{ Erosion protection } & 1 & Very high & Mixed Mediterranean macchia/evergreen forests & 1 \\
\hline & 2 & high & Mediterranean macchia, pine forests, Permanent grasslands, evergreen perennial crops & 1.3 \\
\hline & 3 & Moderate & Deciduous forests & 1.6 \\
\hline & 4 & Low & Deciduous perennial agricultural crops (almonds, orchards) & 1.8 \\
\hline & 5 & Very Low & Annual agricultural crops (cereals), annual grasslands, vines, & 2 \\
\hline \multirow[t]{5}{*}{ Drought resistance } & 1 & Very high & Mixed Mediterranean macchia/evergreen forests, Mediterranean macchia & 1 \\
\hline & 2 & high & Conifers, deciduous, olives & 1.2 \\
\hline & 3 & Moderate & Perennial agricultural trees (vines, almonds, ochrand) & 1.4 \\
\hline & 4 & Low & Perennial grasslands & 1.7 \\
\hline & 5 & Very Low & Annual agricultural crops, annual grasslands & 2 \\
\hline \multirow[t]{3}{*}{ Plant cover } & 1 & high & $>40 \%$ & 1 \\
\hline & 2 & Low & $20-40 \%$ & 1.8 \\
\hline & 3 & Very Low & $<20 \%$ & 2 \\
\hline
\end{tabular}


Table 7 Main management indicators in study area source: INS, ODCO, ODS (Copernicus open access hub n.d.; Office de développement du Centre ouest (ODCO) 2017; Office de développent du Sud (ODS) 2017)

\begin{tabular}{|c|c|c|c|c|c|c|}
\hline $\begin{array}{l}\text { Delegation (administrative } \\
\text { subdivision) }\end{array}$ & $\begin{array}{l}\text { Population (2017) } \\
\text { (inhabitant) }\end{array}$ & Area & $\begin{array}{l}\text { Population } \\
\text { density }\end{array}$ & $\begin{array}{l}\text { Livestock } \\
\text { (head) }\end{array}$ & $\begin{array}{l}\text { Grazeland } \\
\text { area }\end{array}$ & $\begin{array}{l}\text { Livestock } \\
\text { density }\end{array}$ \\
\hline Mezzouna & 25535 & 1119 & 22.81 & 39250 & 161.41 & 35.07 \\
\hline Belkhir & 14882 & 8395 & 17.72 & 22350 & 817.02 & 26.62 \\
\hline Meknassy & 24327 & 625 & 38.92 & 24380 & 124.195 & 39.00 \\
\hline Menzel Bouzayane & 26012 & 590 & 44.08 & 26240 & 149.2 & 44.47 \\
\hline Guettar & 20466 & 910 & 22.49 & 18850 & 887.03 & 20.71 \\
\hline
\end{tabular}

1c image 5 , in this case band 8 and 4 (eq. 7) (Copernicus open access hub n.d.).

$$
\mathrm{NDVI}=\frac{(N I R-R)}{(N I R+R)}=\frac{(B A N D 8-B A N D 4)}{(B A N D 8+B A N D 4)}
$$

Where NIR is the near infra-red band and $R$ is the red band.

Then, a supervised classification of image produced a land use map that was a basis for calculating parameters of drought resistance, fire resistance and erosion protection (Fig. 5). All four parameters were weighted with scores provided in model and multiplied with following equation (Eq. 8) (Table 6):

$$
\begin{aligned}
\mathrm{VQI}= & (\text { fire risk } * \text { erosion protection } \\
& * \text { drought resistance } * \text { vegetation cover })^{1 / 4}
\end{aligned}
$$

\section{Management quality index}

Calculation of management index was obtained after land use map was completed to assess land use intensity. Data on population density in study area were provided by National Institute of Statistics and assigned according to an administrative subdivision followed by an extraction of study region (Institut national des statistiques 2014). Overgrazing data were obtained using statistics from regional development centers in central west and south (Office de développement du Centre ouest (ODCO) 2017; Office de développent du Sud (ODS) 2017). Calculation of overgrazing was done according to head rate per square kilometer based on sheep head as a calculation unit. Bovine heads have been multiplied by four to equal sheep heads (Table 7). Water erosion conservation facilities have been digitized from (c)Google earth app.. Bouhedma natural reserve extension was provided by Carte Agricole (Ministry of agriculture 2001). After weighted scores were assigned, the four

Table 8 Assigned weighing indices for various parameters used for assessment of management quality (Kosmas et al. 1999; UNESCO - United Nations Educational: Scientific and Cultural Organization 1979; Vieira et al. 2015))

\begin{tabular}{llll}
\hline Parameter & Description & Range & \\
\hline Cropland (land use) & low land use intensity & & \\
& Medium land use intensity & & \\
& high land use intensity & & \\
population density & & $<10$ inhabitants per square $\mathrm{km}$ & 2 \\
& & $10-20$ inhabitants per square $\mathrm{km}$
\end{tabular}




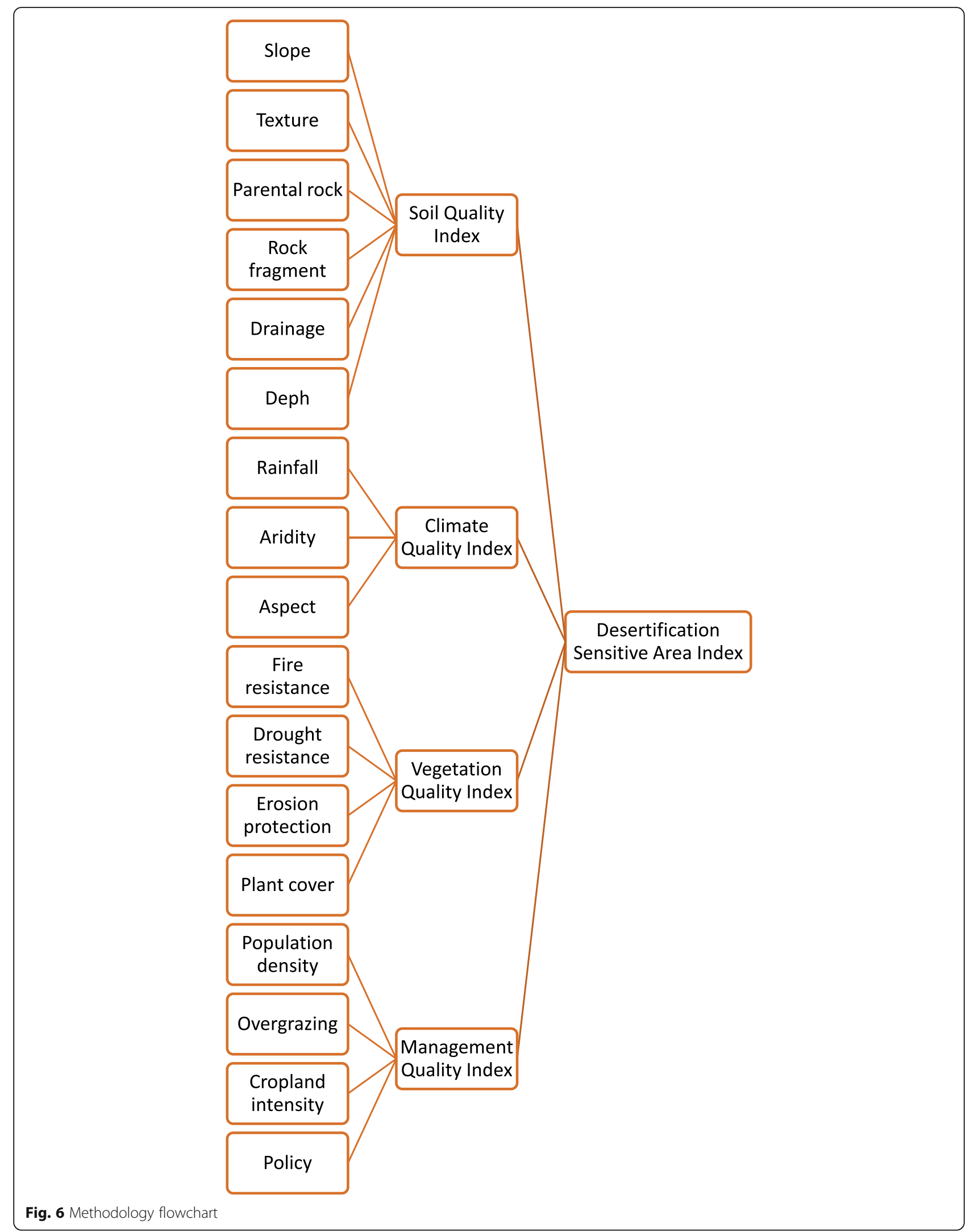




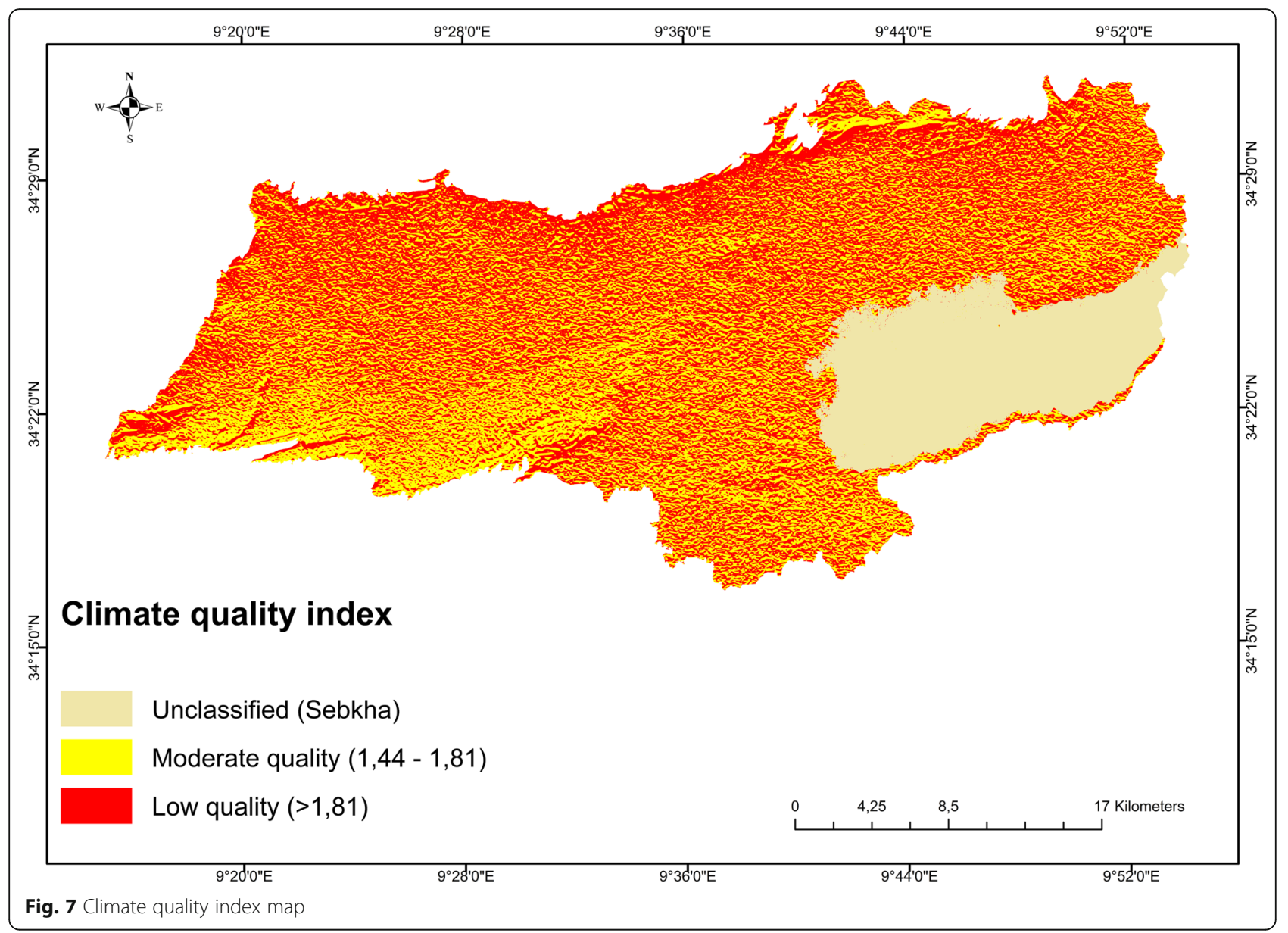

parameters were multiplied according to following equation (Eq. 9) (Table 8):

$$
\begin{aligned}
\mathrm{MQI}= & (\text { cropland } * \text { population density } \\
& * \text { overgrazing } * \text { policy })^{1 / 4}
\end{aligned}
$$

\section{Desertification-sensitive areas index}

Map of final index of desertification-sensitive areas is based on multiplication, in a GIS system, in this case ArcGis software (Fig. 6). Superimposition of different layers in vector format is done by Overlay_union tool. Equation is applied in final integration field through field calculator box (eq. 10):

$$
\mathrm{ESAI}=(\mathrm{SQI} * \mathrm{CQI} * \mathrm{VQI} * \mathrm{MQI})^{1 / 4}
$$

Where ESAI is desertification-sensitive areas index, SQI is soil quality index, CQI is climate quality index, VQI is vegetation quality index and MQI is managementquality index
Table 9 Spatial distribution of climate quality index classes

\begin{tabular}{llll}
\hline Class & Value & Area sq. km & $\%$ \\
\hline Unclassified (sebkha) & 0 & 139.26 & 14.26 \\
Moderate quality & $1.15-1.81$ & 389.22 & 40.03 \\
Low quality & $>1.81$ & 443.69 & 45.63 \\
\hline
\end{tabular}

Table 10 Spatial distribution of soil quality index classes

\begin{tabular}{llll}
\hline Class & Value & Area & $\%$ \\
\hline Unclassified (sebkha) & 0 & 139.26 & 14.26 \\
Moderate quality & $1.13-1.45$ & 606.02 & 62.08 \\
Low quality & $>1.45$ & 230.81 & 23.64 \\
\hline
\end{tabular}




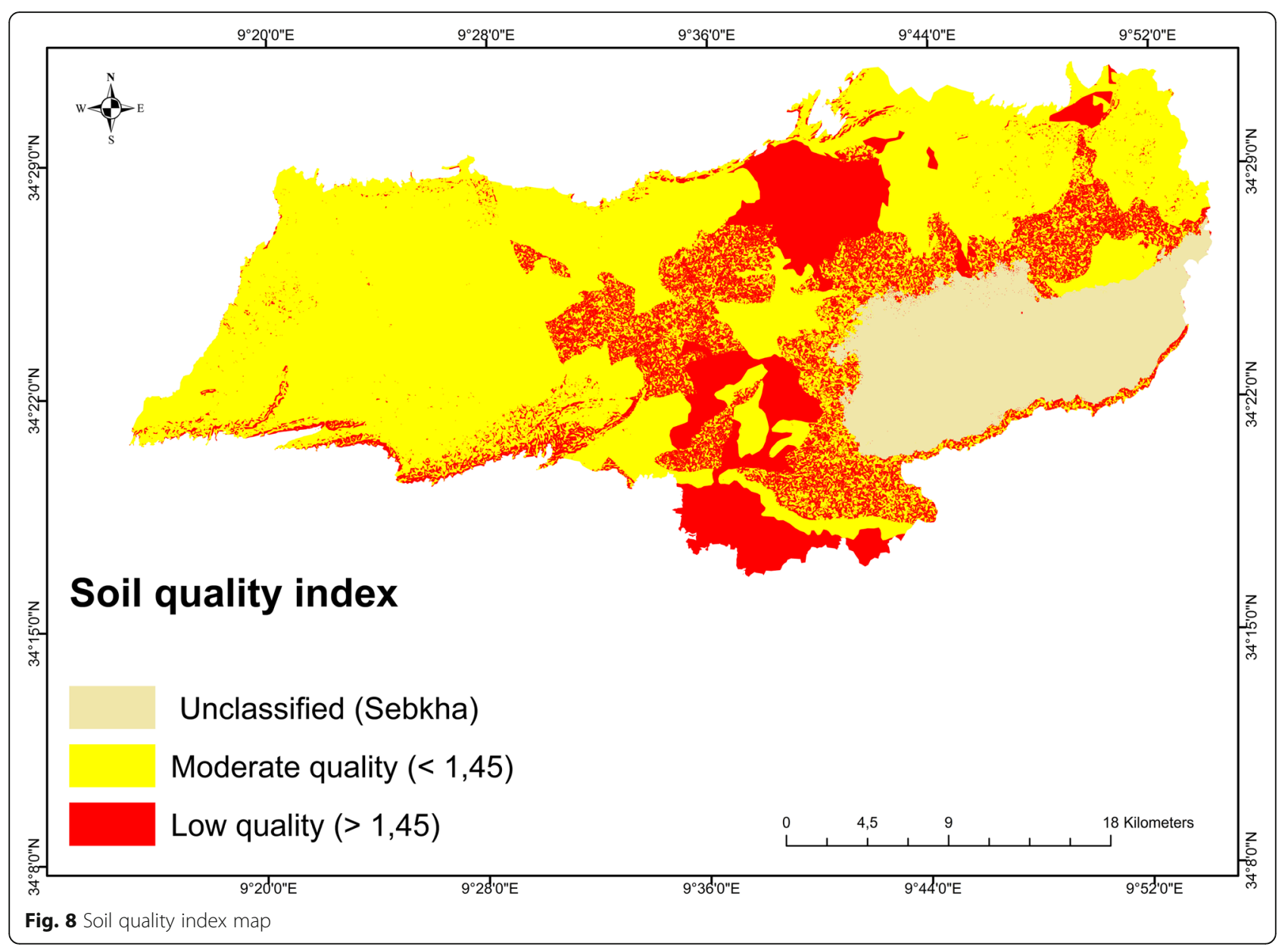

\section{Results and discussions}

\section{Climate quality index}

By examining this index, areas of study region are almost divided between moderate quality $(40 \%)$ and low climate quality (45\%) (Fig. 7) (Table 9).. This map is strongly influenced by terrain exposition map (Aspect) which assigns a value to each set of pixels with same exposition. All climatic parameters included in this index inputs prove that study area is in an arid zone. Only exposure to North has somewhat reduced aridity of some areas.

\section{Soil quality index}

Soil quality map shows that $62 \%$ are in moderate quality class and 23\% in low quality one. Most of land (85\%) in

Table 11 Spatial distribution of vegetation quality index classes

\begin{tabular}{llll}
\hline Class & Value & Area & $\%$ \\
\hline Unclassified (sebkha) & 0 & 139.26 & 14.26 \\
Moderate quality & $1.2-1.6$ & 394.84 & 40.01 \\
Low quality & $>1.6$ & 450.88 & 45.68 \\
\hline
\end{tabular}

region is therefore of moderate or low quality, which makes it particularly fragile (Fig. 8) (Table 10). It also shows that low-quality soils are in central plain where cropping activities in region are concentrated, resulting in degradation of superficial soil horizons due to trampling, deep tillage (seed) or surface tillage (grass cleaning). Continued pressure in this area affects soils that have become fragile, thin and impoverished. Remaining areas, of moderate quality, are due to complexity of their development because of parent rocks that are still very close, crop-unfriendly crusting and presence of steeper slopes.

Table 12 Spatial distribution of management quality index classes

\begin{tabular}{llll}
\hline Class & Value & Area sq. km & $\%$ \\
\hline Unclassified (sebkha) & 0 & 139.26 & 14.26 \\
High quality & $<1.25$ & 61.59 & 6.19 \\
Moderate quality & $1.5-1.50$ & 546.10 & 54.95 \\
Low quality & $>1.50$ & 247.01 & 24.85 \\
\hline
\end{tabular}




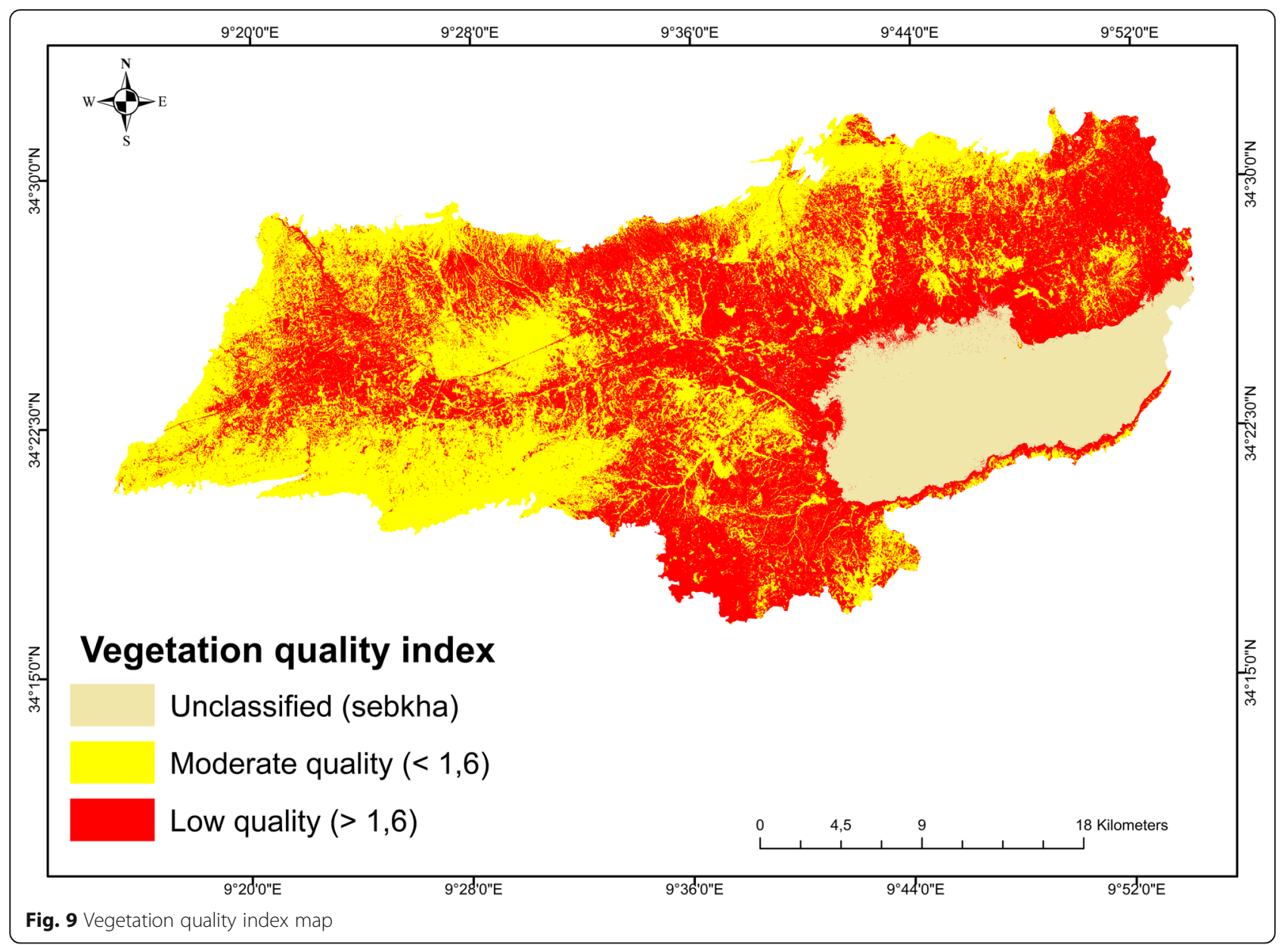

\section{Vegetation quality index}

This map shows that $40 \%$ of land in study region is in moderate quality and $45 \%$ in low quality (Fig. 9) (Table 11). As a result, these areas are poorly or not covered by protective vegetation, exposing them to erosion factors. Medium-quality vegetation terrain corresponds to unprotected grasslands, extensive arboriculture, often young and with very poor covering for soil. Irrigated plots, therefore intensive, are too isolated and are not significant areas to change situation. Areas of poor

Table 13 Spatial distribution of desertification sensitivity areas index classes

\begin{tabular}{llll}
\hline Class & Value range & area sq. $\mathrm{km}$ & $\%$ \\
\hline Unclassified (Sebkha) & 0 & 139.26 & 14.26 \\
Fragile 2 & $<1.2$ & 2.86 & 0.29 \\
Fragile 3 & $1.32-1.37$ & 27.93 & 2.87 \\
Critical 1 & $1.37-1.41$ & 83.09 & 8.56 \\
Critical 2 & $1.41-1.53$ & 583.03 & 60.09 \\
Critical 3 & $>1.53$ & 133.97 & 13.81 \\
\hline
\end{tabular}

vegetation quality are zones without vegetation other than xerophilous or annual species with very low coverage.

\section{Management quality index}

On management quality and land use map, 6\% of land has good protection and management quality, $54 \%$ is in moderate class and $24 \%$ has a low management quality (Fig. 10) (Table 12). Only area that benefits of good management and therefore protection is that of Bouhedma natural reserve where forest authorities have set up a strict system to prohibit any illegal grazing or illegal use of wood from rare shrub species of acacia raddiana. Areas of moderate quality correspond to zones that have been protected by conservation practices against water erosion. Remaining areas, of low management quality, are all simply unprotected rangelands.

\section{Desertification sensitive areas index}

Desertification sensitivity map produced by overlaying the four thematic maps shows high sensitivity values affecting most of the study area. Thus, $0.29 \%$ of the 


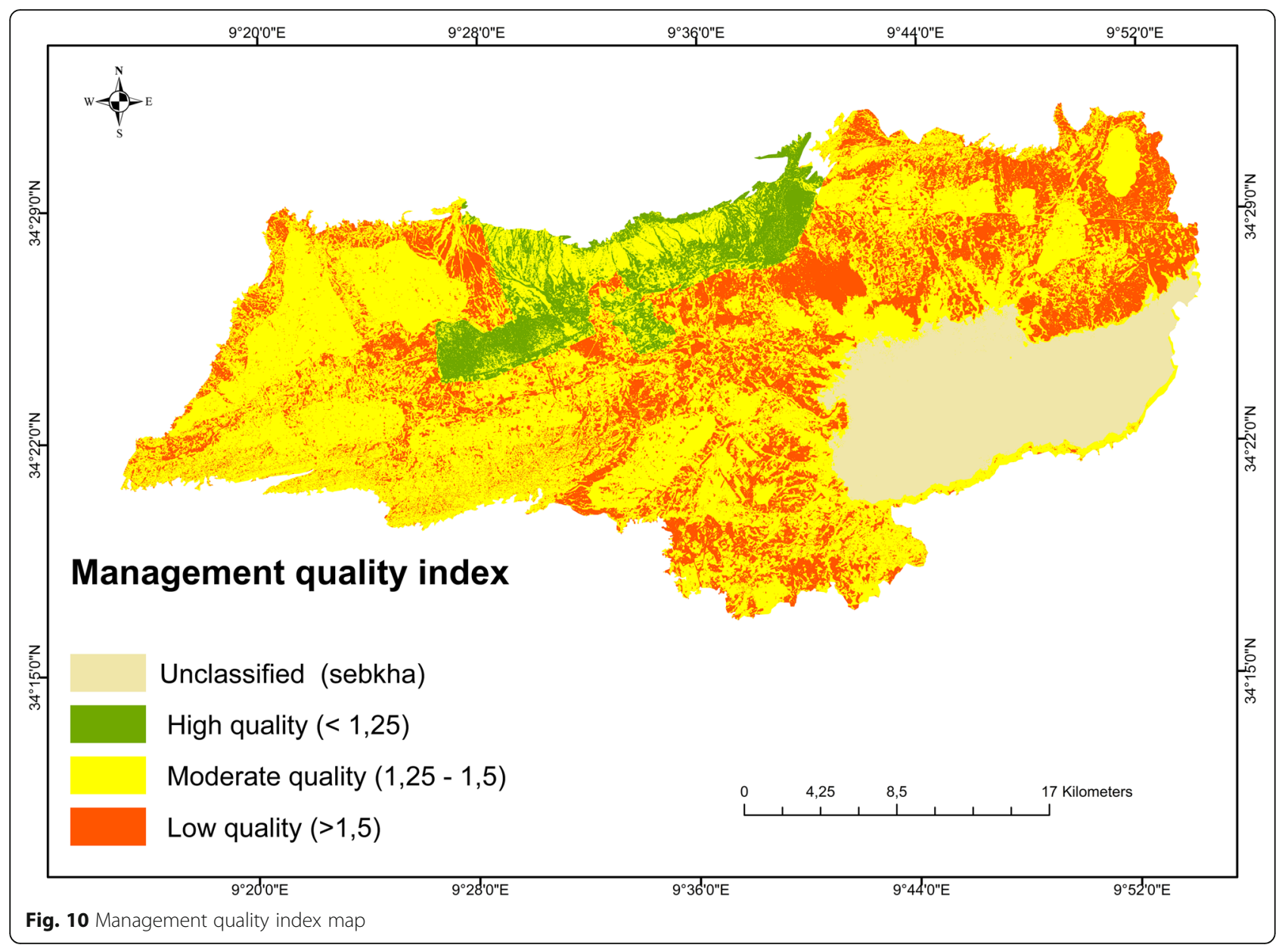

land belongs to class F2 (Fragile 2), $2.87 \%$ of the land to class F3 (Fragile 3), 8.56\% to class C1 (Critical 1), $60 \%$ to class $\mathrm{C} 2$ and 13 to maximum class C3 (Fig. 11) (Table 13). Critical class covers $82 \%$ of surface area with its three subclasses. This clearly shows that study region is extremely sensitive to desertification given its physical and management characteristics. As shown on this map we can distinguish:

- Areas of the fragile class:

* Relatively less sensitive areas (but which remain in the fragile class) correspond to lands in the natural reserve where grazing, cutting wood, ploughing, etc. are strictly forbidden. Trampling is also low since entry is also prohibited, except for the wild fauna living there.

* Areas in south-western part of the map that are poorly cultivated by man due to slopes or crusting unfavorable to crops, or areas with conservation practices to prevent water erosion.

- Areas of critical subclasses 1 and 2:
Critical subclass 1 and 2 areas cover most of study area. Their degradation is in progress and requires rapid intervention, notably by creating rangelands closed to use for a period of time allowing natural vegetation to regenerate and soil to stabilize. A multiplication of land conservation facilities to prevent water and wind erosion, but also by initiating an ambitious reforestation program, which paradoxically is still lacking, would be salutary for the region.

\section{- Areas of critical subclass 3:}

Subclass C3 covers the entire eastern half of study region and corresponds to sectors with poor quality soils but which are paradoxically heavily used in farming and the least protected against erosion. These lands are very sensitive to desertification due to cultural practices used, particularly dry farming requiring repeated ploughing. The latter proves to be damaging to soil because it releases particles and makes available to wind and water erosion the best soil elements which are organic matter and fine fraction. Their protection would start with a profound change in 


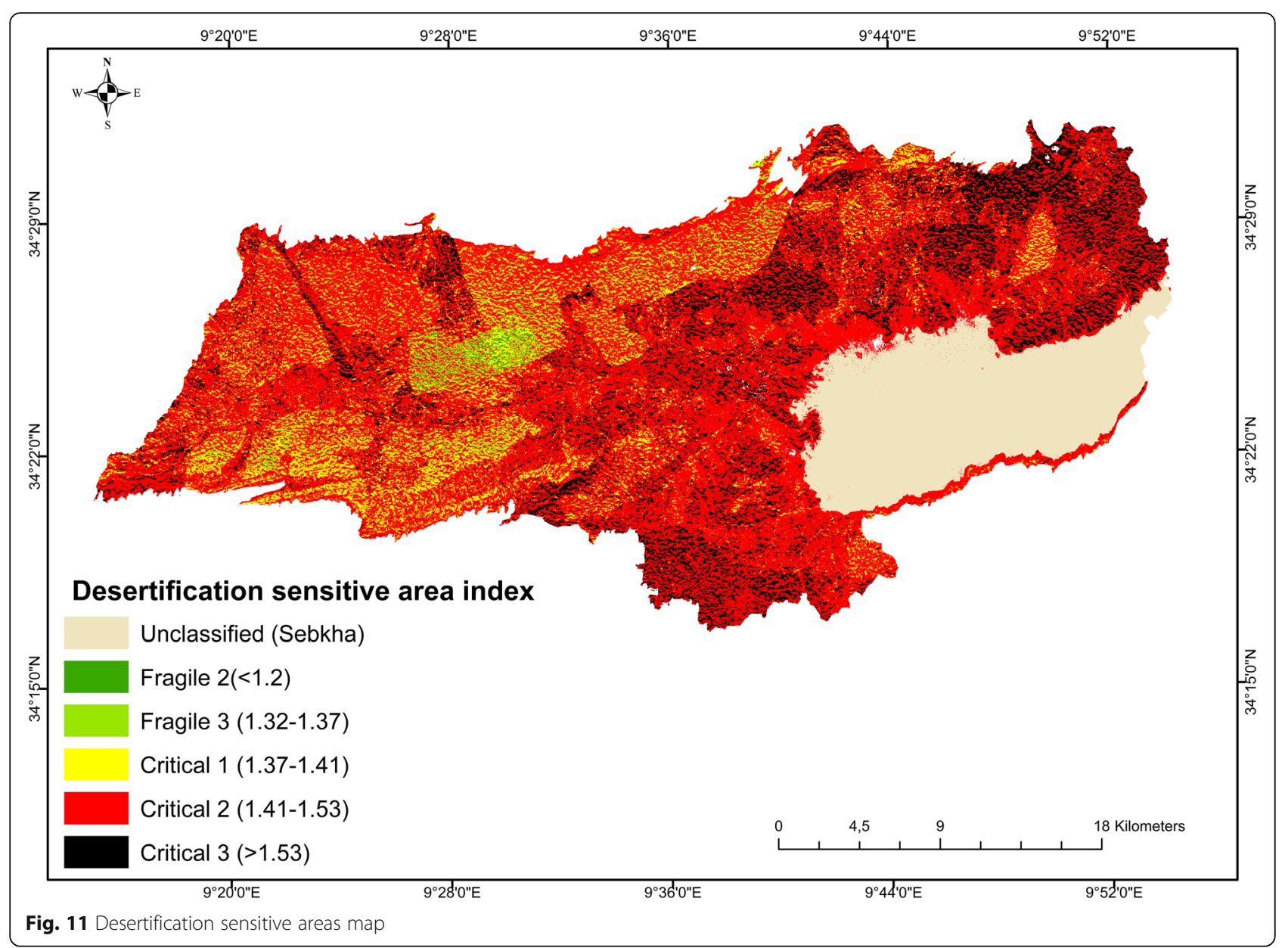

farming methods, which must take into account soil weakness. Generalization of conservation techniques to prevent erosion would also help to reduce loss of essential soil elements.

\section{Conclusion}

In this study, objective was to use physical and human parameters integrated in a GIS environment and following MEDALUS model guidelines, in order to assess desertification sensitivity of a steppe region in south-central Tunisia. All parameters were first weighted and calculated individually to produce indices of climate, vegetation, soil and management. They were then superimposed to produce final desertification sensitivity index. Study region is characterized primarily by a substantially arid climate. This was reflected in calculation of this index by $85 \%$ of its area with a moderate or low-quality climate (45\% for the latter category). Low rainfall and water deficit, exacerbated by high evapotranspiration during most months of year, often explain this situation. Poor and low-structured soils predispose region to desertification. Most of land in region (85\%) has soils of moderate or low quality (including $23 \%$ for the latter category), indicating an increased sensitivity to degradation. Thin depth of soils, their destruction by livestock and use of ploughing are often behind their current state. Rare and sparse vegetation contributes to fragility of the region. $85 \%$ of lands have moderate to low quality vegetation (45\% of which is of low quality). Except for protected natural reserve, which allows vegetation regeneration and soil stabilization, area's land suffers from poor protection by vegetation. This is due to scarcity of trees and xerophilic aspect of shrubs and perennials which are still under threat of illegal cutting despite cutting being prohibited for certain species (acacia raddiana). Human management in this vulnerable region is highly responsible for desertification extension. $78 \%$ of land has human management of moderate or poor quality (including $24 \%$ for the latter). This shows that human management is clearly not compatible with current environmental conditions. Analysis of desertification sensitivity index of study area shows that it is at an advanced stage of desertification since most of its 
surface area (82\%) has been classified in critical category. Remaining part is considered as fragile. This place the entire region in high desertification sensitivity classes. This state is linked to a combination of multiple factors, including a lack of vegetation cover, unstructured and poorly developed soils, tillage-based cropping practices and livestock heads numbers in regard to low natural grazing resources. As a result, there is a remarkable pressure on natural resources, especially since they are not able to regenerate as quickly in the current context of exploitation.

\begin{abstract}
Abbreviations
MEDALUS: Mediterranean Desertification and Land Use; GIS: Geographic information system; MERRA: Modern-Era Retrospective analysis for Research and Applications; ETP: Evapotranspiration; DEM: Digital elevation model; NDVI: Normalized difference vegetation index; ESAl: Environment-sensitive areas index; CQI: Climate quality index; SQI: Soil quality index; VQI: Vegetation quality index; MQI: Management quality index
\end{abstract}

\section{Acknowledgements}

Not Applicable.

\section{Authors' contributions}

The author has prepared and written all parts of this article himself. The author read and approved the final manuscript.

\section{Funding}

No funding was received for this work.

\section{Availability of data and materials}

All data sources supporting the conclusions of this article are publicly available in their respective web links except for the agricultural map (Ministry of agriculture 2001) which can be obtained from the author under reasonable request.

\section{Competing interests}

The author declare that he has no competing interests.

Received: 16 August 2019 Accepted: 24 March 2020

Published online: 12 May 2020

\section{References}

Basso F, Belloti A, Fareta S, Ferara A, Marino G, Pisante M, Quaranta G, Tabemer M (1999) The Agri Basin In: Basso et al, 1999. Mediterranean desertification and land use. manual on key indica- tors of desertification and mapping environmentally sensitive areas to desertification, in: ftp://ftp.Fao.Org/agl

Boudjemline F, Semar A (2018) Assessment and mapping of desertification sensitivity with MEDALUS model and GIS—case study: basin of Hodna, Algeria. J Water Land Dev:17-26 [CrossRef]

Bouhata R, Kalla M (2014) Mapping of environmental vulnerability of desertification by adaptation of the MEDALUS method in the endoreic area of gadaine (eastern Algeria). Geogr Tech 09:1-8

Budak M, Günal H, Celik I, Yıldız H, Acir N, Acar A (2018) Environmental sensitivity to desertification in northern Mesopotamia; application of modified MEDALUS by using analytical hierarchy process. Arab J Geosci 11:481

Copernicus open access hub (n.d.). Sentinel-2 1c 10m resolution imagery. https:// scihub.copernicus.eu/dhus/\#/home

Institut national des études stratégiques (Tunisie) (2017) Revue stratégique de la sécurité alimentaire et nutritionnelle en Tunisie, p 246 https://www.google. $\mathrm{com} /$ url?sa $=t \& r c t=j \& q=\&$ esr $c=s \&$ source $=$ web $\& c d=1 \&$ ved $=2$ ahUKEwjGrt24 ruTjAhUPYVAKHd7HBogQFjAAegQIARAC\&url=http\%3A\%2F\%2Fwww.onagri. nat.tn\%2Fuploads\%2FEtudes\%2Fsecurite\%2520alimentaire.pdf\&usg= AOVVawOrdbLfSPaymfiw1dMo6fOd

Institut national des statistiques (2014) Recensement général de la population et des ménages. Gouvernorat de Sidi Bouzid et de Gafsa
Kamel A, Ali H, Ghaleb F, Mario M, Tony G (2015) GIS-based mapping of areas sensitive to desertification in a semi-arid region in Lebanon. South-Eastern Eur J Earth Obs Geomat 4:91-103

Kosmas C, Kirkby MJ, Geeson N (eds) (1999) Medalus project: Mediterranean desertification and land use. Manual on KEY INDICATORS of desertification and mapping environmentally sensitive areas. Publication of European Union, Brussels ISBN 9282863492. https://www.researchgate.net/ publication/262374822_Methodology_for_mapping_Environmentally_ Sensitive_Areas_ESAs_to_desertification

Lahlaoi H, Rhinane H, Hilali A, Lahssini S, Moukrim S (2017) Desertification assessment using MEDALUS model in watershed Oued El Maleh, Morocco. Geosciences 7:50 [CrossRef]

Le Mouël C, Forslund A, Marty P, Manceron S, Marajo-Petitzon E, Caillaud M-A, Schmitt B (2015) Le système agricole et alimentaire de la région Afrique du Nord - Moyen-Orient à l'horizon 2050 : projections de tendance et analyse de sensibilité. Rapport final de l'étude réalisée pour le compte de Pluriagri, Paris et Rennes : INRA-DEPE \& INRA-SAE2, p 133 https://www.google.fr/

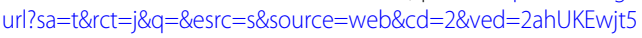
KfrteTjAhUKWZOKHQ9xAllQFjABegQIBRAC\&url=https\%3A\%2F\%2Fwww6.paris. inra.fr\%2Fdepe\%2Fcontent\%2Fdownload\%2F3862\%2F36656\%2Ffile\%2FR\%25 C3\%25A9sum\%25C3\%25A9_8_pages\%2520Etude_Inra_Pluriagri_28_10_2015. pdf\&usg=AOvVaw0cBafdjs-jn_YHSgl9rFin

Malhue H, Isabel A (2018) Análisis de la evolución de las áreas ambientalmente sensibles a la desertificación en la cuenca del Puangue en Chile. Idesia 36(4): 61-70. https://doi.org/10.4067/S0718-34292018005002801 ISSN 0718-3429

Ministry of agriculture (2001). La carte agricole (the agricultural map), governorate of Sidi Bouzid (digital database as shapefiles), 480 megabytes

Momirović N, Kadović R, Perović V, Marjanović M, Baumgertel A (2018) Spatial assessment of the areas sensitive to degradation in the rural in the rural area of the municipality Čukarica. Int Soil Water Conserv Res. https://doi.org/10. 1016/j.jiswcr.2018.12.004

NASA (n.d.-a): Digital Elevation Model 28m resolution accessible at https://lpdaac. usgs.gov/dataset_discovery/aster/aster_products_table

NASA (n.d.-b): Solar radiation data (Soda), (Modern-Era Retrospective analysis for Research and Applications, Version 2 (MERRA-2)), Merra_2 climatological gridded data accessible at (http://www.soda-pro.com/web-services/meteo$\mathrm{data} / \mathrm{merra})$

National office of mines (n.d.), Geological map at 1/50000 sheets n 120, 113. Geological map at 1/500000 southern part

Office de développement du Centre ouest (ODCO) (2017): Le gouvernorat Sidi Bouzid en chiffres

Office de développent du Sud (ODS) (2017): Le gouvernorat de Gafsa en chiffres

Office of Topography and Cartography (n.d.), Tunisia. Topographic map, 1/50000 sheets $n^{\circ} 113,120,121$ )

Sampaio EVSB, Araújo MSB, Sampaio YSB (2003) Propensão à desertificação no semi-árido brasileiro. Rev Geogr 22:59-76

Sepehr A, Hassanli AM, Ekhtesasi MR, Jamali JB (2007) Quantitative assessment of desertification in south of Iran using MEDALUS method. Environ Monit Assess 11134(1-3):243-254

Thornthwaite CW (1948) An approach toward a rational classification of climate Geogr Rev 38:55-94. https://doi.org/10.2307/210739

UNESCO - United Nations Educational: Scientific and Cultural Organization, Map of the world distribution of arid regions: map at scale $1: 25000000$ with explanatory note, MAB technical notes 7, UNESCO, 1979. https://www.google.fr/url?sa=t\&rct= $j \& q=\& e s r c=s \&$ source $=$ web\&cd $=1 \&$ ved=2ahUKEwjD9LipoenjAhXJb1 AKHWXhAZsQFjAAegQIARAC\&url=https\%3A\%2F\%2Funesdoc.unesco.org\%2Fin\%2 Frest\%2FannotationSVC\%2FDownloadWatermarkedAttachment\%2Fattach_ import_586231 15-6143-4260-ae6d-3fa9bdofbe1f\%3F_\%3D032661engo.pdf\&usg= AOVVawOIYC2ZRF53MRPCIWNLIPET

Vieira RMSP, Tomasella J, Alvala RCS, Sestini MF, Affonso AG, Rodriguez DA, Barbosa AA, Cunha APMA, Valles GF, Crepani E, De Oliveira SBP, De Souza MSB, Calil PM, Carvalh MA, Valeriano DM, Campello FCB, Santana MO (2015) Identifying areas susceptible to desertification in the Brazilian northeast. Solid Earth 6:347-360 https://www.google.fr/url?sa=t\&rct=j\&q=\&esrc=s\&source= web\&cd=1\&cad=rja\&uact=8\&ved=2ahUKEwiozeKloenjAhVKKIAKHV6AC5 AQFjAAegQIABAB\&url=https\%3A\%2F\%2Fwww.solid-earth.net\%2F6\%2F347\%2 F2015\%2Fse-6-347-2015.html\&usg=AOVVaw1OYRpv-i6hzblLQJgaGXJ8

\section{Publisher's Note}

Springer Nature remains neutral with regard to jurisdictional claims in published maps and institutional affiliations. 